\title{
Pengaruh Ampas Tebu Terhadap Pertumbuhan dan Produktivitas Tanaman Terong Hijau
}

\author{
B. Wafiroh ${ }^{1}$, F.R. Esti Wahyuni ${ }^{2}$, Benediktus Ege ${ }^{3}$, Yakobus Bustami ${ }^{4 *}$, \& Markus Iyus \\ Supiandi ${ }^{4}$ \\ 1,2,3,4 Program Studi Pendidikan Biologi, STKIP Persada Khatulistiwa Sintang, Sintang \\ Corresponding Author: ybustami07@gmail.com \\ Manuscript received: 12-02-2018 Revision accepted: 20-04-2018
}

\begin{abstract}
Abstrak
Penelitian ini bertujuan untuk mengetahui pengaruh ampas tebu terhadap pertumbuhan dan produktivitas tanaman terong hijau. Pendekatan yang digunakan dalam penelitian ini adalah pendekatan kuantitatif dengan metode penelitian eksperimen. Rancangan dalam penelitian menggunakan rancangan acak lengkap (RAL) setiap perlakuan terdiri dari 5 ulangan. Data yang akan diukur tinggi tanaman, panjang daun, jumlah daun dan jumlah buah. Alat pengumpul data dalam penelitian ini menggunakan lembar observasi dan dokumentasi berupa foto. Analisis data menggunakan analisis deskriptif dan inferensial. Analisis inferensial menggunakan uji anova dan dilanjutkan dengan uji Least Significanca Different (LSD). Hasil penelitian menunjukkan bahwa pemberian ampas tebu memberikan pengaruh yang signifikan terhadap pertumbuhan dan produktivitas tanaman terong hijau. Pertumbuhan tanaman terong hijau dengan pemberian ampas tebu menghasilkan rata-rata tinggi tanaman $(27,8)$, panjang daun $(20,77)$, jumlah daun (11 helai) dan jumlah buah ( 8 buah). Hasil ini diperkuat dengan analisis sidik ragam yaitu $f_{\text {hitung }}>f_{\text {tabel }}$ dimana tinggi tanaman $(33,38>2,87)$, panjang daun $(33,39>2,87)$, jumlah daun $(41,89>2,87)$ dan jumlah buah $(32>2,87)$. Selanjutnya, Uji Least Significanca Different (LSD) menunjukkan bahwa ampas tebu perlakuan keempat (1500 gram) berpengaruh optimal terhadap pertumbuhan dan produktivitas tanaman terong hijau.
\end{abstract}

Kata kunci: ampas tebu, pertumbuhan, produktivitas, terong hijau

\begin{abstract}
This research aims to determine the effect of bagasse on the growth and productivity of Solanum melongena. The approach used in this study is a quantitative approach with experimental research method. The design in the research using complete randomized design (RAL) each treatment consisted of 5 replications. The data to be measured plant height, leaf length, number of leaves and number of fruits. The data collection in this research use observation sheet and documentation in the form of photo. The data analysis using descriptive and inferential analysis. The Inferential analysis using anova test and continued with Least Significanca Different (LSD) test. The results showed that the provision of bagasse could have a significant effect on the growth and productivity of Solanum melongena. Growth of Solanum melongena with bagasse giving average plant height $(27,8)$, leaf length $(20,77)$, number of leaves (11 pieces) and number of fruit (8 pieces). This result was reinforced by analysis of variance $f_{\text {count }}>f_{\text {table, }}$ where height of plant $(33,38>2,87)$, leaf length $(33,39>2,87)$, number of leaf $(41,89>2,87)$ and number of fruit $(32>2,87)$. Furthermore, Least Significanca Different (LSD) test showed that the fourth treatment bagasse (1500 grams) had an optimal effect on the growth and productivity of Solanum melongena.
\end{abstract}

Keywords: bagasse, growth, productivity, Solanum melongena 


\section{PENDAHULUAN}

Budidaya terong yang baik sangat dibutuhkan dalam rangka memenuhi kebutuhan asupan nutrisi. Komposisi kimia tanaman terong per 100 gram yaitu air 92,7 gram; zat besi 0,4 mg; karbohidrat 5,5 gram; lemak 0,2 gram; kalori 24,00 kal; fosfor $37 \mathrm{mg}$; kalsium $15 \mathrm{mg}$; protein 1,1 gram; natrium 4,00 mg; vitamin B1 0,04 mg; vitamin A 30 S.I; vitamin C 5,00 mg (Haryoto, 2013: 13).

Di Indonesia, terong sering disajikan dalam berbagai hidangan, mulai dari sayuran berkuah hingga lalapan. Potensi pasar terong juga dapat dilihat dari segi harga yang terjangkau oleh seluruh lapisan masyarakat sehingga membuka peluang yang lebih besar terhadap serapan pasar dan petani. Berdasarkan hasil survei ke pedagang menunjukkan bahwa tanaman terong termasuk salah satu sayuran yang paling banyak dicari oleh masyarakat. Jumlah konsumsi terong mengalami peningkatan tiap tahunnya, namun hal ini tidak diiringi dengan jumlah produksi yang meningkat. Kondisi tanah yang ideal untuk media tanam terong adalah memiliki kadar $\mathrm{pH}$ antara 5-7. Kisaran suhu yang dibutuhkan untuk perkembangbiakan tanaman terong antara $22-30{ }^{\circ} \mathrm{C}$ (Haryoto, 2013:13).

Produktivitas tanaman terong di Indonesia memiliki hasil terong rata-rata yaitu 32,64 - 34,11 kuintal/hektar, padahal untuk luasan satu hektar dapat dihasilkan 30 ton terong. Berdasarkan data yang diperkuat dari Badan Pusat Statistik Provinsi Sulawesi Tengah tahun 2010 luas areal tanaman terong 1.425 / ha dengan produksi 8,365 ton, dengan hasil per hektar 58,62 kuintal/hektar (Kahar dkk, 2016). Menurut Wiebe (Adhitya dkk, 2013) "produktivitas pertanian sangat penting dalam menciptakan ketahanan pangan dan lahan sangat berpengaruh dalam peningkatan produktivitas pertanian". Salah satu faktor yang penting dalam peningkatan produktivitas lahan pertanian komoditas tanaman pangan adalah pengelolaan lahan.

Ketersediaan lahan pertanian di Indonesia diperlukan untuk mencukupi kebutuhan pangan penduduk yang semakin meningkat. Namun faktanya luas lahan tidak mampu menyediakan produktivitas tanaman terong hijau. Perkembangan lahan tanaman pangan sebagai sarana produksi yang terdiri dari lahan sawah dan lahan kering pada tahun 1995 sebesar 10,42 juta hektar dan berubah menjadi 10,99 juta hektar pada tahun 2004, sehingga laju pertumbuhannya per tahun sebesar 0,60 persen (Adhitya dkk, 2013). Lahan di Indonesia yaitu berupa tanah misalnya seperti tanah vulkanik, tanah humus, tanah lempung atau liat dan tanah kapur.

Salah satu yang diperlukan dalam budidaya tanaman adalah media pertumbuhannya. Media tanam yang digunakan harus disesuaikan dengan jenis tanaman. Menurut Fitriani (2011: 8), menyatakan bahwa media tanam gambut campuran tanah akan mempunyai kemampuan untuk menyimpan air dan udara untuk pertumbuhan tanaman paling tinggi dibanding media tanam lain". Menurut Fitrianah dkk (2012: 35) memperlihatkan bahwa "Komposisi media tanam 1:1 memberikan komponen pertumbuhan tinggi pada panjang tanaman dan jumlah daun. Komposisi media tanam 2:1 memberikan komponen pada luas daun".

Salah satu media tanam yang dapat digunakan untuk membudidayakan tanaman terong hijau adalah dengan menggunakan campuran ampas tebu. Ampas tebu merupakan bahan berserat sisa proses pengolahan pada industri gula. Menurut (Andriyanti dkk, 2012: 2) ampas tebu merupakan sisa bagian batang tebu dalam proses ekstraksi tebu yang memiliki kadar air 
berkisar $46-52 \%$, kadar serat $43-52 \%$ dan padatan terlarut sekitar 2-6\%. Komposisi kimia ampas tebu meliputi: zat arang atau Karbon (C) 23,7\%, Hidrogen (H) 2\%, Oksigen (O) $20 \%$, Air $\left(\mathrm{H}_{2} \mathrm{O}\right) 50 \%$ dan Gula 3\%. Disisi lain, serat ampas tebu terdiri dari selulosa, pentosan dan lignin. Komposisi ketiga komponen bisa bervariasi pada varietas tebu yang berbeda.

Penggunaan ampas tebu dilakukan dengan cara pengomposan ampas tebu menggunakan mikroorganisme lokal (MOL). Menurut Anonim (2013) "Mol buah-buahan mengandung unsur $\mathrm{N}$ dan $\mathrm{P}$ yang agak berimbang sangat baik untuk pertumbuhan vegetatif tanaman karena mengandung karbohidrat yang terdapat pada air cucian beras, glukosa pada air kelapa, gula merah dan buah-buahan sebagai sumber mikroorganisme". Menurut Sri dkk (2015) juga mengatakan "Larutan MOL mengandung unsur hara makro,mikro, dan mengandung mikroorganisme yang berpotensi sebagai perombak bahan organik, perangsang pertumbuhan, dan agen pengendali hama dan penyakit tanaman sehingga baik digunakan sebagai dekomposer, pupuk hayati, dan pestisida organik".

\section{METODE PENELITIAN}

Pendekatan penelitian ini adalah kuantitatif dengan jenis penelitian eksperimen. Penelitian ini menggunakan Rancangan Acak Lengkap (RAL). Perlakuan yang akan diuji merupakan kombinasi dari ampas tebu dan tanah. Setiap perlakuan terdiri dari 5 ulangan, dan masingmasing ulangan di tanam satu individu tanaman. Rancangan penelitian yang akan dilakukan peneliti termuat pada Tabel 1 berikut.

Tabel 1. Perlakuan dengan Campuran Ampas Tebu (Saccharum officinarum L.)

\begin{tabular}{crrrrr}
\hline \multirow{2}{*}{ Perlakuan } & \multicolumn{5}{c}{ Ulangan } \\
\cline { 2 - 6 } & U1 & U2 & U3 & U4 & U5 \\
\hline C1 & C1U1 & C1U2 & C1U3 & C1U4 & C1U5 \\
P2 & P2U1 & P2U2 & P2U3 & P2U4 & P2U5 \\
P3 & P3U1 & P3U2 & P3U3 & P3U4 & P3U5 \\
P4 & P4U1 & P4U2 & P4U3 & P4U4 & P4U5 \\
P5 & P5U1 & P5U2 & P5U3 & P5U4 & P5U5 \\
\hline
\end{tabular}

\footnotetext{
Keterangan:

$\mathrm{C} 1($ Kontrol 1) $=$ ampas tebu $=0 \%=0 \mathrm{gr}(\mathrm{kontrol})$

P2 $($ Perlakuan 2$)=$ ampas tebu $=25 \%=500 \mathrm{gr}$

P3 $($ Perlakuan 3$)=$ ampas tebu $=50 \%=1000 \mathrm{gr}$

P4 (Perlakuan 4$)=$ ampas tebu $=75 \%=1500 \mathrm{gr}$

P5 $($ Perlakuan 5$)=$ ampas tebu $=100 \%=2000$ gr

$\mathrm{U} 1$ = Ulangan 1

$\mathrm{U} 2$ = Ulangan 2

$\mathrm{U} 3$ = Ulangan 3

$\mathrm{U} 4$ = Ulangan 4

U5 = Ulangan 5
}

Alat dalam penelitian ini berupa: parang, terpal, gembor, timbangan, polybag, sekop, penggaris, bolpoint, dan benang. Bahan dalam penelitian ini berupa: ampas tebu, cairan MOL, air, tanah bakar, dan bibit tanaman terong hijau.

Prosedur penelitian terdiri dari tiga tahapan yaitu pembuatan Mikroorganisme lokal (MOL), pengomposan ampas tebu dan penanaman tanaman terong hijau. Untuk lebih jelasnya tahapan penelitian dapat dilihat pada Tabel 2, Tabel 3, dan Tabel 4. 
Tabel 2. Prosedur Pembuatan Mikroorganisme Lokal (Mol)

\begin{tabular}{ll}
\hline No. & \multicolumn{1}{c}{ Prosedur } \\
\hline 1. & Menyiapkan semua alat dan bahan \\
2. & Lubangi tutup toples menggunakan pisau \\
3. & Masukkan selang dan kemudian rekatkan menggunakan lilin agar udara tidak \\
& masuk \\
4. & Potong buah pepaya menjadi bagian kecil-kecil kemudian remas-remas \\
5. & Masukan buah pepaya ke dalam toples \\
6. & Tambahkan air cucian beras dan air kelapa dengan konsentrasi \\
& yang berbeda, air cucian beras sebanyak 3 liter dan air kelapa sebanyak 1 liter \\
7. & Tambahkan gula merah secukupnya \\
8. & Aduk semua campuran bahan sampai rata \\
9. & Tutup toples sisa kan ruang sekitar 3 jari dan usahakan selang tidak menyentuh \\
& cairan mol. \\
10. & Agar tidak ada udara yang masuk rekatkan tutup toples menggunakan lakban. \\
11. & Diamkan mol selama \pm 15-17 hari
\end{tabular}

Tabel 3. Prosedur Pengomposan Ampas Tebu

\begin{tabular}{ll}
\hline No. & \multicolumn{1}{c}{ Prosedur } \\
\hline 1. & Siapkan bahan dan alat \\
2. & Gelar terpal dan tumpahkan ampas tebu. Terpal digunakan untuk membungkus \\
ampas tebu. & Campurkan MOL pepaya dengan takaran 3 liter MOL dan air 4 liter. \\
3. & Siramkan dengan menggunakan gembor secara merata sehingga semua ampas \\
tebu basah. & \\
5. & Aduk rata dan tutup rapat terpal dan diamkan selama \pm 30 hari. Dalam waktu \\
& seminggu sekali siramkan dengan cairan MOL pepaya dengan takaran sama. \\
\hline
\end{tabular}

Tabel 4. Prosedur Penanaman dan Pemberian Tanaman Terong Hijau (Solanum melongena L)

\begin{tabular}{|c|c|}
\hline No. & Prosedur \\
\hline 1. & Menyiapkan alat dan bahan yang digunakan selama proses penelitian. \\
\hline 2. & $\begin{array}{l}\text { Terlebih dulu bibit terong disemai, lahan umtuk penyemaian kurang lebih seluas } \\
50 \times 50 \mathrm{~cm} \text {. Penyemaian membutuhkan waktu } \pm \text { seminggu. }\end{array}$ \\
\hline 3. & $\begin{array}{l}\text { Menyiapkan media tanam yang akan digunakan dengan cara mengisi polybag } \\
\text { dengan tanah yang sudah dicampurkan dengan ampas tebu. Biarkan polybag yang } \\
\text { sudah diisi dengan tanah yang sudah dicampurkan dengan ampas tebu selama } 1-2 \\
\text { hari sebelum ditanami, agar tercampur rata dan unsur hara yang dibutuhkan } \\
\text { terbentuk. }\end{array}$ \\
\hline 4. & $\begin{array}{l}\text { Penyusunan polybag sesuai denah dimaksud agar pengamatan dapat dilakukan } \\
\text { dengan mudah bagi peneliti. }\end{array}$ \\
\hline 5. & $\begin{array}{l}\text { Pencabutan bibit dari area persemaian dilakukan dengan hati-hati. Caranya } \\
\text { dengan membuat lubang sedalam } 5-10 \mathrm{~cm} \text { menggunakan tongkat kayu ataupun } \\
\text { jari tangan. Kemudian masukkan bibit terong hijau yang telah disemai ke dalam } \\
\text { lubang tersebut. }\end{array}$ \\
\hline 6. & $\begin{array}{l}\text { Pemberian perlakuan dilakukan dengan menggunakan campuran ampas tebu } \\
\text { sebagai media tanam. Penambahan pemberian perlakuan dilakukan setiap } 2 \\
\text { minggu sekali. }\end{array}$ \\
\hline
\end{tabular}




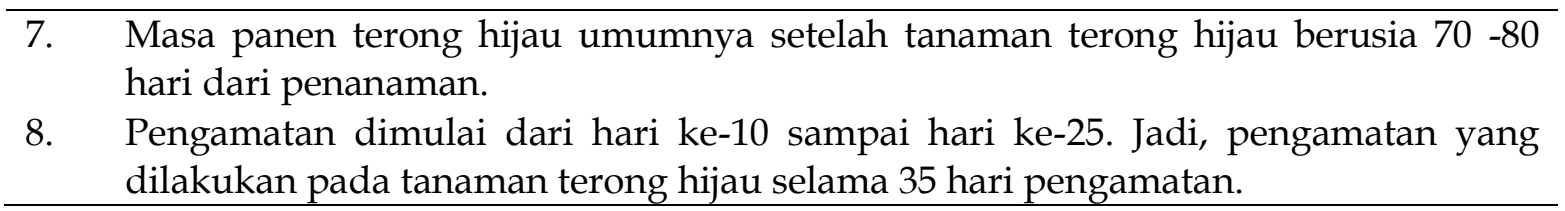

Parameter yang diukur dalam penelitian ini meliputi tinggi tanaman, panjang daun, jumlah daun dan jumlah buah. Sedangkan metode dokumentasi berupa catatan lapangan berupa catatan tertulis yang dibuat oleh peneliti dalam sebuah penelitian di lapangan. Analisis data menggunakan analisis deskriptif dan inferensial. Analisis inferensial menggunakan uji Anova dan dilanjutkan dengan uji Least Significance Different (LSD) pada taraf $0.05 \%$ untuk melihat beda nyata dari setiap perlakuan. Analisis data dihitung menggunakan perhitungan SPSS versi 23.

\section{HASIL PENELITIAN}

Hasil yang diperoleh dalam penelitian ini merupakan semua data yang dikumpulkan selama penelitian di lapangan. Berdasarkan hasil analisis deskriptif menunjukkan rerata terhadap beberapa parameter pertumbuhan dalam penelitian ini yaitu sebagai berikut:

\section{Tinggi Tanaman}

Pengukuran dilakukan pada saat tanaman berusia 42 hari setelah tanam. Pengukuran dapat dilihat pada rerata pertumbuhan tinggi tanaman terong hijau yang disajikan dalam Tabel 5 . Hasil penelitian pada Tabel 5 menunjukkan bahwa pertumbuhan tinggi tanaman dengan menggunakan media kompos ampas tebu setelah 42 hari masa tanam menunjukan kecenderungan meningkat. Pada hari ke-42, tinggi tanaman yang paling tinggi ditemukan pada perlakuan keempat (dosis 1500 gram) dengan rerata 39,340 cm. Adapun perlakuan yang memberikan pengaruh terhadap tinggi tanaman yang paling rendah adalah perlakuan kesatu (0 gram) dengan rerata 19,900 cm. Selanjutnya hasil analisis dengan menggunakan analisis anova pertumbuhan tinggi tanaman akibat menggunakan media tanam berupa kompos ampas tebu terhadap tinggi tanaman terong hijau dari hari ke-42 dapat dilihat pada Tabel 6.

Tabel 5. Nilai Rerata Pertumbuhan Tinggi Tanaman Hijau

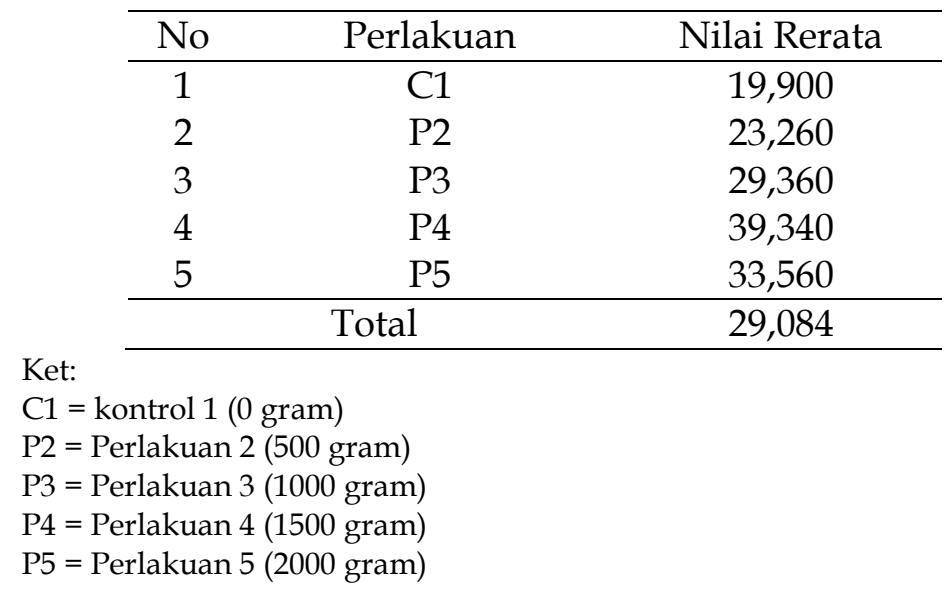


Tabel 6. Hasil Anova Rancangan Acak Lengkap Tinggi Tanaman Terong Hijau Akibat Pengaruh Penggunaan Media Tanam Ampas Tebu

\begin{tabular}{lccccc}
\hline Source & $\begin{array}{c}\text { Type III Sum of } \\
\text { Squares }\end{array}$ & df & Mean Square & F & Sig. \\
\hline Corrected Model & $1217,806^{\mathrm{a}}$ & 4 & 304,451 & 33,400 &, 000 \\
Intercept & 21146,976 & 1 & 21146,976 & 2319,918 &, 000 \\
perlakuan & 1217,806 & 4 & 304,451 & 33,400 &, 000 \\
Error & 182,308 & 20 & 9,115 & & \\
Total & 22547,090 & 25 & & & \\
\hline Corrected Total & 1400,114 & 24 & & & \\
\hline a. R Squared $=, 870$ (Adjusted R Squared $=, 844)$ & & &
\end{tabular}

Hasil penelitian pada Tabel 6. menunjukkan bahwa $\mathrm{H}_{1}$ diterima yaitu terdapat pengaruh yang signifikan ampas tebu terhadap tinggi tanaman terong hijau $(33,40>2,87)$. Selanjutnya dilanjutkan dengan uji Least Significance Different (LSD) pada taraf 5\% untuk melihat ada tidaknya pengaruh yang nyata dengan menggunakan ampas tebu dan yang tidak diberi perlakuan. Hasil uji Least Significance Different (LSD) dapat dilihat pada Tabel 7.

Tabel 7. Hasil Uji Least Significance Different (LSD) pada taraf 5\% Pertumbuhan Tinggi Tanaman Terong Hijau

\begin{tabular}{llccccc}
\hline Perlakuan & Ulangan & Nilai Rerata & Std. Deviasi & Nilai Cor & \multicolumn{2}{c}{ Notasi LSD } \\
\hline Kontrol & 0 gram & 19,900 & 1,9987 & 17,084 & a & \\
Ampas tebu & 500 gram & 23,260 & 3,7567 & 20,444 & a & \\
& 1000 gram & 29,360 & 2,8632 & 26,544 & & b \\
& 1500 gram & 39,340 & 2,3565 & 36,524 & & c \\
& 2000 gram & 33,560 & 3,7038 & 30,744 & & c \\
\hline
\end{tabular}

Berdasarkan hasil uji Least Significance Different (LSD) menunjukkan bahwa perlakuan keempat (dosis 1500) paling nyata berpengaruh terhadap perlakuan lainnya pada pertumbuhan tanaman terong hijau.

2) Panjang Daun

Pengukuran dilakukan pada saat tanaman berusia 42 hari setelah tanam. Pengukuran dapat dilihat pada rerata pertambahan panjang daun terong hijau yang disajikan dalam Tabel 8 . Hasil penelitian pada Tabel 8 menunjukkan bahwa pertambahan panjang daun dengan menggunakan media ampas tebu setelah 42 hari masa tanam menunjukan kecenderungan meningkat. Pada hari ke-42, panjang daun yang paling panjang ditemukan pada perlakuan keempat (dosis 1500 gram) dengan rerata $24,640 \mathrm{~cm}$. Adapun perlakuan yang memberikan pengaruh terhadap panjang daun yang paling rendah adalah perlakuan kesatu (dosis 0 gram) dengan rerata $14,040 \mathrm{~cm}$. Selanjutnya hasil analisis dengan menggunakan analisis Anova pertambahan panjang daun akibat menggunakan media tanam berupa ampas tebu terhadap panjang daun terong hijau dari hari ke-42 dapat dilihat pada Tabel 9. 
Tabel 8. Nilai Rerata Pertumbuhan Panjang Daun Terong Hijau

\begin{tabular}{ccc}
\hline No & Perlakuan & Nilai Rerata \\
\hline 1 & C1 & 14,040 \\
2 & P2 & 16,600 \\
3 & P3 & 20,200 \\
4 & P4 & 24,640 \\
5 & P5 & 21,800 \\
\hline
\end{tabular}

Ket:

$$
\begin{aligned}
& \text { C1 }=\text { kontrol } 1(0 \text { gram }) \\
& \text { P2 }=\text { Perlakuan } 2 \text { (500 gram) } \\
& \text { P3 }=\text { Perlakuan } 3(1000 \text { gram) } \\
& \text { P4 }=\text { Perlakuan } 4 \text { (1500 gram) } \\
& \text { P5 }=\text { Perlakuan } 5 \text { (2000 gram) }
\end{aligned}
$$

Tabel 9. Hasil Anova Rancangan Acak Lengkap Panjang Daun Terong Hijau Akibat Pengaruh Penggunaan Media Tanam Ampas Tebu

\begin{tabular}{lccccc}
\hline Source & $\begin{array}{c}\text { Type III Sum of } \\
\text { Squares }\end{array}$ & df & Mean Square & F & Sig. \\
\hline Corrected Model & $352,058^{a}$ & 4 & 88,014 & 33,591 &, 000 \\
Intercept & 9463,398 & 1 & 9463,398 & 3611,708 &, 000 \\
Perlakuan & 352,058 & 4 & 88,014 & 33,591 &, 000 \\
Error & 52,404 & 20 & 2,620 & & \\
Total & 9867,860 & 25 & & & \\
\hline Corrected Total & 404,462 & 24 & & & \\
\hline a. R Squared $=, 870$ (Adjusted R Squared $=, 845)$ & & & &
\end{tabular}

Hasil penelitian pada Tabel 9. menunjukkan bahwa $\mathrm{H}_{1}$ diterima yaitu terdapat pengaruh yang signifikan ampas tebu terhadap panjang daun tanaman terong hijau $(33,59>2,87)$. Selanjutnya dilanjutkan dengan uji Least Significance Different (LSD) pada taraf 5\% untuk melihat ada tidaknya pengaruh yang nyata dengan menggunakan ampas tebu dan yang tidak diberi perlakuan. Hasil uji Least Significance Different (LSD) dapat dilihat pada Tabel 10.

Tabel 10. Hasil Uji Least Significance Different (LSD) pada taraf 5\% Pertumbuhan Panjang Daun Tanaman Terong Hijau

\begin{tabular}{llccccc}
\hline Perlakuan & Ulangan & Nilai Rerata & Std. deviasi & Nilai Cor & \multicolumn{2}{c}{ Notasi LSD } \\
\hline Kontrol & 0 gram & 14,040 & 1,2482 & 12,530 & a & \\
Ampas tebu & 500 gram & 16,600 & 1,5395 & 15,090 & a & \\
& 1000 gram & 20,200 & 1,8908 & 18,690 & & b \\
& 1500 gram & 24,640 & 1,5884 & 23,130 & & c \\
& 2000 gram & 21,800 & 1,7536 & 20,290 & & c \\
\hline
\end{tabular}

Berdasarkan hasil uji Least Significance Different (LSD) menunjukkan bahwa perlakuan keempat (dosis 1500 gram) paling nyata berpengaruh terhadap perlakuan lainnya terhadap pertumbuhan panjang daun tanaman terong hijau. 


\section{3) Jumlah Daun}

Pengukuran dilakukan pada saat tanaman berusia 42 hari setelah tanam. Pengukuran dapat dilihat pada rerata pertumbuhan jumlah daun terong hijau yang disajikan dalam Tabel 11. Hasil penelitian pada Tabel 11. menunjukkan bahwa pertambahan jumlah daun dengan menggunakan media ampas tebu setelah 42 hari masa tanam menunjukan kecenderungan meningkat. Pada hari ke-42, jumlah daun yang paling panjang ditemukan pada perlakuan keempat (dosis 1500 gram) dengan rerata 15,000 cm. Adapun perlakuan yang memberikan pengaruh terhadap jumlah daun yang paling rendah adalah perlakuan kesatu (0 gram) dengan rerata $7,400 \mathrm{~cm}$. Selanjutnya hasil analisis dengan menggunakan analisis Anova pertumbuhan jumlah daun akibat menggunakan media tanam berupa ampas tebu terhadap jumlah daun terong hijau dari hari ke-42 dapat dilihat pada Tabel 12.

Tabel 11. Nilai Rerata Pertumbuhan Jumlah Daun Terong Hijau

\begin{tabular}{ccc}
\hline No & Perlakuan & Nilai Rerata \\
\hline 1 & C1 & 7,400 \\
2 & P2 & 10,200 \\
3 & P3 & 11,600 \\
4 & P4 & 15,000 \\
5 & P5 & 12,600 \\
\hline \multicolumn{2}{c}{ Total } \\
\hline
\end{tabular}

Ket:

$\mathrm{C} 1=\operatorname{kontrol} 1(0$ gram $)$

P2 = Perlakuan 2 (500 gram)

P3 = Perlakuan 3 (1000 gram)

P4 = Perlakuan 4 (1500 gram)

P5 = Perlakuan 5 (2000 gram)

Tabel 12. Hasil Anova Rancangan Acak Lengkap Jumlah Daun Terong Hijau Akibat Pengaruh Penggunaan Media Tanam Ampas Tebu

\begin{tabular}{lccccc}
\hline Source & $\begin{array}{c}\text { Type III Sum of } \\
\text { Squares }\end{array}$ & df & Mean Square & F & Sig. \\
\hline Corrected Model & $159,360^{a}$ & 4 & 39,840 & 21,890 &, 000 \\
Intercept & 3226,240 & 1 & 3226,240 & 1772,659 &, 000 \\
perlakuan & 159,360 & 4 & 39,840 & 21,890 &, 000 \\
Error & 36,400 & 20 & 1,820 & & \\
Total & 3422,000 & 25 & & & \\
\hline Corrected Total & 195,760 & 24 & & & \\
\hline a. R Squared $=, 814$ (Adjusted R Squared $=, 777)$ & & &
\end{tabular}

Hasil penelitian pada Tabel 12. menunjukkan bahwa $\mathrm{H}_{1}$ diterima yaitu terdapat pengaruh yang signifikan ampas tebu terhadap jumlah daun tanaman terong hijau $(21,89>2,87)$. Selanjutnya dilanjutkan dengan uji Least Significance Different (LSD) pada taraf 5\% untuk melihat ada tidaknya pengaruh yang nyata dengan menggunakan ampas tebu dan yang tidak diberi perlakuan. Hasil uji Least Significance Different (LSD) dapat dilihat pada Tabel 13. 
Tabel 13. Hasil Uji Least Significance Different (LSD) pada taraf 5\% Pertumbuhan Jumlah Daun Tanaman Terong Hijau

\begin{tabular}{llccccc}
\hline Perlakuan & Ulangan & Nilai Rerata & Std. deviasi & Nilai Cor & \multicolumn{2}{c}{ Notasi LSD } \\
\hline Kontrol & 0 gram & 7,400 &, 5477 & 6,141 & $\mathrm{a}$ & \\
Ampas tebu & 500 gram & 10,200 & 1,7889 & 8,941 & $\mathrm{a}$ & \\
& 1000 gram & 11,600 & 1,5166 & 10,341 & & $\mathrm{~b}$ \\
& 1500 gram & 15,000 & 1,0000 & 13,741 & & $\mathrm{c}$ \\
& 2000 gram & 12,600 & 1,5166 & 11,341 & & $\mathrm{c}$ \\
\hline
\end{tabular}

Berdasarkan hasil uji Least Significance Different (LSD) menunjukkan bahwa perlakuan keempat (dosis 1500 gram) paling nyata berpengaruh terhadap perlakuan lainnya terhadap pertumbuhan jumlah daun terong hijau.

4) Jumlah Buah

Pengukuran jumlah buah dilakukan pada saat tanaman 72 hari setelah tanam. Pengukuran dapat dilihat pada rerata pertambahan jumlah buah terong hijau hari ke 72 setelah tanam yang disajikan dalam Tabel 14. Hasil penelitian pada Tabel 14. menunjukkan bahwa pertambahan jumlah buah dengan menggunakan media ampas tebu setelah 72 hari masa tanam menunjukkan kecenderungan stabil. Pada hari ke-72, jumlah buah yang paling banyak ditemukan pada perlakuan keempat (dosis 1500 gram) dengan rerata 4,000. Adapun perlakuan yang memberikan pengaruh terhadap jumlah buah yang paling rendah adalah perlakuan kesatu (0 gram) dengan rerata 2,400. Selanjutnya hasil analisis dengan menggunakan analisis Anova pertumbuhan jumlah buah akibat menggunakan media tanam berupa kompos ampas tebu terhadap jumlah buah terong hijau dari hari ke-52 sampai hari ke72 dapat dilihat pada Tabel 15.

Tabel 14. Rerata Pertumbuhan Jumlah Buah Tanaman Terong Hijau

\begin{tabular}{|c|c|c|c|}
\hline & No & Perlakuan & Nilai Rerata \\
\hline & 1 & $\mathrm{C} 1$ & 2,400 \\
\hline & 2 & P2 & 2,800 \\
\hline & 3 & P3 & 3,200 \\
\hline & 4 & P4 & 4,000 \\
\hline & 5 & P5 & 3,200 \\
\hline & \multicolumn{2}{|r|}{ Total } & 3,120 \\
\hline $\begin{array}{l}\text { Ket: } \\
\text { C1 = kontrol } 1 \\
\text { P2 = Perlakuan } \\
\text { P3 = Perlakuan } \\
\text { P4 = Perlakuan } \\
\text { P5 = Perlakuan }\end{array}$ & $\begin{array}{l}0 \text { gram }) \\
2(500 \mathrm{~g} \\
3(1000 \\
4(1500 \\
5(2000\end{array}$ & & \\
\hline
\end{tabular}


Tabel 15. Hasil Anova Rancangan Acak Lengkap Jumlah Buah Terong Hijau Akibat Pengaruh Penggunaan Media Tanam Ampas Tebu

\begin{tabular}{cccccc}
\hline & Type III Sum of & & & & \\
Source & Squares & df & Mean Square & F & Sig. \\
\hline Corrected Model & $7,040^{a}$ & 4 & 1,760 & 3,667 &, 021 \\
Intercept & 243,360 & 1 & 243,360 & 507,000 &, 000 \\
perlakuan & 7,040 & 4 & 1,760 & 3,667 &, 021 \\
Error & 9,600 & 20 &, 480 & & \\
Total & 260,000 & 25 & & & \\
\hline Corrected Total & 16,640 & 24 & & & \\
\hline
\end{tabular}

a. R Squared $=, 423$ (Adjusted R Squared $=, 308$ )

Hasil penelitian pada Tabel 15 menunjukkan bahwa $\mathrm{H}_{1}$ diterima yaitu terdapat pengaruh yang signifikan ampas tebu terhadap jumlah buah tanaman terong hijau $(3,67>2,87)$. Selanjutnya dilanjutkan dengan uji Least Significance Different (LSD) pada taraf 5\% untuk melihat ada tidaknya pengaruh yang nyata dengan menggunakan ampas tebu dan yang tidak diberi perlakuan. Hasil uji Least Significance Different (LSD) dapat dilihat pada Tabel 16.

Tabel 13. Hasil Uji Least Significance Different (LSD) pada taraf 5\% Pertumbuhan Jumlah Buah Tanaman Terong Hijau

\begin{tabular}{llccclc}
\hline Perlakuan & Ulangan & Nilai Rerata & Std. deviasi & Nilai Cor & Notasi LSD \\
\hline Kontrol & 0 gram & 2,400 &, 5477 & 1,754 & $\mathrm{a}$ & \\
Ampas tebu & 500 gram & 2,800 &, 8367 & 2,154 & $\mathrm{a}$ & \\
& 1000 gram & 3,200 &, 8367 & 2,554 & $\mathrm{a}$ & \\
& 1500 gram & 4,000 &, 7071 & 3,354 & & $\mathrm{~b}$ \\
& 2000 gram & 3,200 &, 4472 & 2,554 & & $\mathrm{c}$ \\
\hline
\end{tabular}

Berdasarkan hasil uji Least Significance Different (LSD) menunjukkan bahwa perlakuan keempat (dosis 1500 gram) paling nyata berpengaruh terhadap perlakuan lainnya terhadap pertumbuhan jumlah buah terong hijau.

\section{PEMBAHASAN}

Berdasarkan hasil penelitian,pengaruh ampas tebu terhadap pertumbuhan dan produkivitas tanaman terong hijau menunjukkan pertumbuhan dan produktivitas yang diberi ampas tebu lebih baik daripada yang tidak diberikan ampas tebu. Berdasarkan hasil analisis deskriptif menunjukkan reratatinggi tanaman terong hijau yaitu $39,340 \mathrm{~cm}$, panjang daun $24,640 \mathrm{~cm}$, jumlah daun 15,000 dan jumlah buah 4,000. Analisis peneliti menunjukkan bahwa pertumbuhan tanaman terong hijau dengan menggunakan ampas tebu dapat meningkatkan pertumbuhan karena, ampas tebu mengandung unsur hara yang diperlukan oleh tanaman. Unsur hara seperti unsur makro dan mikro. Unsur makro meliputi unsur $\mathrm{N}, \mathrm{K}$, dan $\mathrm{P}$ sementara itu, unsur mikro meliputi unsur Ca dan Zn. Analisis peneliti didukung oleh hasil penelitian (Kusuma dkk, 2010) pertumbuhan tinggi tanaman, panjang daun, dan jumlah daun tanaman terong ini diduga bahwa dengan penggunaan media tanam ampas tebu dapat menyebabkan terdorongnya atau terpacunya sel di ujung batang untuk segera mengadakan pembelahan dan pembesaran sel terutama di daerah meristematis dikarenakan ampas tebu mengandung unsur hara makro kalsium. 
Hal ini sesuai dengan pendapat Suprayitno (Kusuma, dkk 2010) "bahwa unsur ini yang paling berperan adalah pertumbuhan sel". Menurut Kusuma (2010) "Kalsium komponen yang menguatkan, dan mengatur daya tembus, serta merawat dinding sel. Perannya sangat penting pada titik tumbuh akar. Bahkan bila terjadi defiensi $\mathrm{Ca}$, pembentukan dan pertumbuhan akar terganggu, dan berakibat penyerapan hara terhambat. Ca berperan dalam proses pembelahan dan perpanjangan sel, dan mengatur distribusi hasil fotosintesis.

Selanjutnya berdasarkan uji analisis menggunakan Anova menunjukkan bahwa $\mathrm{H}_{1}$ diterima yaitu terdapat pengaruh yang signifikan ampas tebu terhadap tinggi tanaman, panjang daun, jumlah daun, dan jumlah buah terong hijau dengan $\mathrm{F}_{\text {hitung }}>\mathrm{F}_{\text {tabel }}$ yaitu tinggi tanaman $(33,40>2,87)$, panjang daun $(33,59>2,87)$, jumlah daun $(21,89>2,87)$, dan jumlah buah $(3,67>2,87)$. Hal ini sesuai dengan hasil penelitian Yuliani (2009) bahwa media jerami, blotong dan ampas tebu dengan berbagai frekuensi penyiraman berpengaruh terhadap pertumbuhan jamur merang (Volvariella volvaceae). Perlakuan campuran ampas tebu dan blotong dengan frekwensi penyiraman dua kali yang diaplikasikan secara tunggal maupun kombinasi memberikan pertumbuhan terbaik dan produktivitas jamur merang tertinggi. Pengaruh salah satu unsur mikro mempunyai peranan penting dalam pertumbuhan dan produktivitas tanaman terong hijau salah satunya seperti unsur Zn yang berperan sebagai aktivator enzim, pembentukan klorofil dan membantu proses fotosintesis (Kusuma dkk, 2010). Selanjutnya penelitian Sulistyowati dan Purnomo (2011) mengatakan bahwa: "pengaruh ampas tebu sebagai media pertumbuhan terhadap jamur tiram menyatakan bahwa media tanam ampas tebu dapat mempengaruhi kecepatan pertumbuhan jamur tiram dan berpengaruh terhadap kualitas fisik serta kandungan nutrisi jamur tiram".

Berdasarkan uji lanjut Least Significance Different (LSD) menunjukkan bahwa pada taraf $5 \%$ pengaruh ampas tebu terhadap tinggi tanaman, panjang daun, jumlah daun dan jumlah buah pada perlakuan keempat (dosis 1500 gram) berbeda nyata dengan pengaruh penggunaan dosis lainnya. Hasil uji Least Significance Different (LSD) dengan (dosis 1500 gram) ampas tebu memberikan hasil yang optimal pada pertumbuhan dan produktivitas tanaman terong hijau. Hal ini didukung dengan adanya penelitian Rahimah dkk (2015), yang berjudul pemanfaatan kompos berbahan baku ampas tebu (Saccharum Sp.) dengan bioaktivator Trichoderma Spp. sebagai media tumbuh semai Acacia crassicarpa mampu meningkatkan pertumbuhan semai Acacia crassicarpa pada medium tanah topsoil. Kompos ampas tebu terformulasi dengan dosis $100 \mathrm{~g} /$ polybag, yang diberikan pada medium tanam dengan volume media $2 \mathrm{~kg}$, menunjukkan peningkatan pertumbuhan semai Acacia crassicarpa terbaik. Menurut Nasution (Rahimah, dkk 2015) "tanaman akan dapat tumbuh subur apabila unsur hara dalam keadaan tersedia dalam tanah, karena pertumbuhan tanaman tergantung dari unsur hara yang diperoleh dari tanah, serta dipengaruhi oleh penambahan unsur hara yang diperoleh dari pemberian pupuk kompos".

Selain unsur Zn dan Ca masih banyak unsur-unsur lain yang terdapat dalam ampas tebu yang mempengaruhi pertumbuhan dan produktivitas tanaman terong hijau. Salah satu unsur yang mempengaruhi pertumbuhan yaitu unsur N. Menurut Soemarno (Dinawati, 2017) "Unsur nitrogen memiliki peran utama bagi tanaman ialah untuk merangsang pertumbuhan tanaman secara keseluruhan, terutama batang, cabang, dan daun jika kekurangan unsur $\mathrm{N}$ gejalanya pertumbuhan lamban/lerdil, daun hijau kekuningan, daun sempit, pendek dan tegak, daundaun tua cepat menguning dan mati". Selanjutnya menurut Yanti (2017) "Nitrogen (N) merupakan unsur hara utama bagi pertumbuhan tanaman, yang pada umumnya sangat diperlukan untuk pertumbuhan tanaman". 
Unsur yang lain yang sangat mempengaruhi dalam pertumbuhan yaitu unsur K. Menurut Pangaribuan dkk (Dinawati, 2017) "unsur Kalium berperan dalam memacu pertumbuhan akar, memperbaiki ketegaran tanaman secara umum, mendorong produksi biji, mengurangi penyerapan racun, meningkatkan kandungan kalsium pada buah serta mengurangi radioaktif". Menurut (Marviana dan Utami 2014) unsur hara khususnya Kalium (K) yang cukup bagi pertumbuhan tanaman terong, karena unsur kalium dapat berpengaruh terhadap proses pembungaan pada tanaman.

Unsur yang turut mempengaruhi pertumbuhan tanaman terong hijau yaitu unsur Fosfor (P). Selain pertumbuhan, unsur $\mathrm{P}$ juga mempengaruhi produktivitas tanaman. Menurut Muhammad, dkk (Huruna dan Maruapey, 2015) “bahwa ketersediaan unsur P bagi tanaman berfungsi mempercepat pembungaan dan pemasakan buah, biji atau gabah serta mempercepat persentase pembentukan bunga menjadi buah atau biji". Selanjutnya menurut Fahmi (Dinawati, 2017) "unsur Fosfor merupakan komponen penting penyusun senyawa untuk transfer energi (ATP dan Nukleoprotein lain), untuk sistem operasi genetik (DNA dan RNA) untuk membran sel (fosofolipid dan fosfoprotein). Sementara itu, menurut Yanti (2017) "fosfor berperan untuk mempercepat pertumbuhan tanaman muda menjadi tanaman dewasa dan berbagai proses metabolisme lainnya". Penggunaan kompos dapat menyediakan unsur hara yang diperlukan bagi tanaman, misalnya unsur hara makro (N, P dan $\mathrm{K}$ ). Bahan organik dalam kompos dapat mengikat unsur hara yang mudah hilang dan menyediakannya bagi tanaman. Melalui pertumbuhan akar yang baik tersebut maka unsur-unsur makro dan mikro lain yang terdapat dalam pupuk ampas tebu dapat terserap dengan mudah dan mencukupi kebutuhan tanaman terong hijau.

\section{SIMPULAN}

Berdasarkan hasil penelitian dan pembahasan yang telah dilakukan peneliti, maka dapat ditarik kesimpulan sebagai berikut: (1) pertumbuhan dan produktivitas tanaman terong hijau (Solanum melongena L) melalui penggunaan media kompos ampas tebu sebagai media tanam menunjukkan pertumbuhan yang lebih baik dari pada tanaman terong hijau (Solanum melongena L) yang tidak diberikan perlakuan kompos ampas tebu; (2) terdapat pengaruh yang nyata penggunaan media kompos ampas tebu sebagai media tanam terhadap pertumbuhan dan produktivitas tanaman terong hijau (Solanum melongena L) yang ditandai dengan adanya pertambahan tinggi tanaman, panjang daun, jumlah daun dan jumlah buah; (3) perlakuan keempat (dosis 1500 gram) penggunaan ampas tebu adalah yang paling baik terhadap pertumbuhan dan produktivitas tanaman terong hijau (Solanum melongena L). Hasil uji BNT membuktikan bahwa perlakuan keempat (dosis 1500 gram) kompos ampas tebu menghasilkan rerata tertinggi untuk semua parameter pertumbuhan dan produktivitas yaitu, pada tinggi tanaman, panjang daun, jumlah daun dan jumlah buah.

Berdasarkan hasil penelitian maka peneliti menyarankan sebagai berikut: (1) Pada penelitian selanjutnya agar dilakukan penelitian dengan dosis perlakuan, jenis tanah, dan tempat yang berbeda terhadap pertumbuhan dan produktivitas tanaman terong hijau (Solanum melongena L); (2) pengomposan ampas tebu dilakukan dengan jangka waktu lebih lama agar mendapat hasil yang baik; (3) Pada penelitian selanjutnya agar dapat dilakukan ujicoba kompos ampas tebu pada jenis tanaman lainnya. 


\section{DAFTAR PUSTAKA}

Adhitya, W. F, Hartono D., dan Awirya, A. A. 2013. Determinan Produktivitas Lahan Pertanian Subsektor Tanaman Pangan di Indonesia. Jurnal Ekonomi Pembangunan. Vol 14. No 1 Hal 110-125.

Andriyanti, W., Suyanti. dan Ngasifudin. 2012. Pembuatan dan Karakterisasi Polimer Superabsorben dari Ampas Tebu. Jurnal Ilmiah Teknologi.Vol 13. No. 1 Hal 2.

Anonim, 2013. Mikroorganisme Lokal, Solusi Bagi Petani. [diakses 5 juli 2013 pada situs http://isroi.wordpress.com].

Dinawati, N. R. 2017. Pengaruh Pupuk Kandang Berbahan Kotoran Ayam terhadap Pertumbuhan Tanaman Cabai Merah (Capsicum annum var. Longum). Skripsi. Tidak diterbitkan.

Eby, K. 2017. Pengaruh Arang Serbuk Kayu Berbantuan Mol Dari Bonggol Pisang Sebagai CampuranMedia Tanam Terhadap PertumbuhanTanaman Terung Ungu (Solanum Melongena L). Skripsi. Tidak diterbitkan.

Ekowati, D., Dan Nasir, M. 2011. Pertumbuhan Tanaman Jagung (Zea Mays L.) Varietas Bisi-2 Pada Pasir Reject Dan Pasir Asli Di Pantai Trisik Kulonprogo (The Growth of Maize Crop (Zea Mays L.). Jurnal Manusia Dan Lingkungan. Vol. 18. No.3 Hal, 220 - 231.

Fitrianah, L., Fatimah S. dan Hidayati, Y. 2012. Pengaruh Komposisi Media Tanam Terhadap Pertumbuhan dan Kandungan Saponin Pada Dua Varietas Tanaman Gendola. Jurnal Agrovigor. Vol 5. No 1 Hal 2.

Fitriani, A. 2011. Pengaruh Jenis Bahan Organik yang Berbeda Sebagai Media Tanam terhadap Pertumbuhan BibitJelutung. Jurnal Agroscientiae. Vol18. No 1 Hal 2.

Haryoto. 2013. Bertanam Terong dalam Pot. Yogyakarta: Kanisius.

Huruna, B., dan Maruapey A. 2015. Pertumbuhan Dan Produksi Tanaman Terung (Solanum melongena L) Pada Berbagai Dosis Pupuk Organik Limbah Biogas Kotoran Sapi. Jurnal Agroforestri. Vol 03. No. 10.

Kahar, Paloloang, A. K., dan Rajamuddin, A. R. 2016. Kadar N, P, K Tanah, Pertumbuhan dan Produksi Tanaman Terung Ungu Akibat Pemberian Pupuk Kandang Ayam dan Mulsa Pada Tanah Entisol Tondo. Jurnal Agrotekbis. Vol 04. No 1 Hal 34-42.

Kemas, A. Hanafiah. 2014. Rancangan Percobaan Teoridan Aplikasi. Jakarta: Rajawali Pers.

Lopita. 2016. Pengaruh Penyiraman Air Teh (Camellia sinensis L.) terhadap Pertumbuhan Tanaman Sawi Hijau (Brassica juncea L). Skripsi. Tidak diterbitkan.

Marviana, D. D. 2014. Respon Pertumbuhan Tanaman Terung (Solanum melongena L.) Terhadap Pemberian Kompos Berbahan Dasar Tongkol Jagung dan Kotoran Kambing Sebagai Materi Pembelajaran Biologi Versi Kurikulum 2013. Skripsi. Program Studi Pendidikan Biologi: Universitas Ahmad Dahlan. Yogyakarta. 
Rahimah, M, Mardhiansyah., dan Yoza D. 2015. Pemanfaatan Kompos Berbahan Baku Ampas Tebu (Saccharum Sp.) dengan Bioaktivator Trichoderma Spp. Sebagai Media Tumbuh Semai Acacia Crassicarpa. JurnalJom Faperta. Vol. 2 No. 1 Hal 3.

Wasis, B. Istantini, A. 2013. Pengaruh Pemberian Arang Tempurung Kelapa dan Kotoran Sapi (Bokashi) terhadap Peningkatan Pertumbuhan Semai Jabon (Anthocephalus cadamba Miq.) pada Media Tanam Tailing Tambang Emas. JurnalSilvikultur Tropika. Vol 4 No.2 Hal 82-87.

Yanti, S. 2017. Pengaruh Konsentrasi Urine terhadap Pertumbuhan Tanaman Tomat (Solanum lycopercium commune). Skripsi. Tidak diterbitkan.

Yuliani, F. 2009. Pertumbuhan dan Produksi Jamur Merang (Volvariella Volvaceae) yang Ditanam pada Media jerami, Blotong dan Ampas Tebu dengan Berbagai Frekuensi Penyiraman. Skripsi. Kudus. Fakultas Pertanian UMK. 